...recuerde el alma dormida 


\title{
La Torre de la inmortalidad
}

\author{
I
}

Como una proa emerges en la Tierra de Campos con la luz de los días que lentamente evocan la tristeza del barro y los ardores del viento en tu impasible rostro de arcilla maltratada.

Fija en un tiempo que ya ni pasa ni regresa frente a la vida que, bajo los tejados, parte su pan de amor caliente duelos y esperanzas de risas callejeras y voces que maldicen.

En tu esquina de ciego te acompaña la noche, la lluvia que acaricia tu cascarón de piedra, el clamor del ocaso, lejanos traqueteos del carro que transita los caminos de siempre.

Y esa mirada lenta de todos los que pasan midiendo la distancia de siglos amansados con sólo esa presencia vertical y silente con que sin prisa te alzas por un cielo constante. 
Una mano de ausencia te arrancó la campana hundiendo en el silencio la vida de unos hombres que van y vienen domesticados por la muerte buscando a su Dios por un surco interminable.

¡Qué sueño de aleluyas guardarán tus maderas picadas por la garra del polvo y el vacío cuando ya no hay respuesta para esa voz que dicta con las figuras del retablo un lánguido credo!

Panera de silencios la torre quebrantada acurruca los santos mutilados y tristes, los estandartes viajeros de un negruzco dorado vencidos gladiadores de antiguas romerías.

Anclada en esta espera, quizá Dios aún regrese con su soplo final desde el monte más lejano redimiendo en la luz de su mirada eterna el tiempo y el olvido que ya no comprendemos.

Becerril de Campos, 1968.

ANDRÉs G. Niño 